\title{
The Anterotica of Petrus Haedus: A Fifteenth-century Model for the
Interpretation of Symbolic Images
}

SHARON A. ADAMS

The habit of drawing meaning from images so characteristic of the Renaissance, with its vogue for mythographic manuals, emblem books, hieroglyphs and imprese, has a long and now well-documented tradition behind it. We are gradually regaining familiarity with these materials and beginning to see how new scholarly insights into their nature affect the interpretation of literary texts where the images in question are not pictorial, but verbal. The Anterotica of Petrus Haedus has a particular interest here; ${ }^{1}$ although it describes a set of conflicting interpretations of a painting of Cupid, no illustrations accompany its text and the image for interpretation is established verbally.

Many scholars have commented upon the nature of the process involved in interpreting symbolic images and certain basic points emerge from their discussions: the openness of the image, its superiority to any particular discursive exploration of its meaning, and the heuristic nature of the process as a path to insight. George Boas's introduction to The Hieroglyphics of Horapollo finds the essence of the emblem in its "fusion of what are called in twentieth-century discussions of poetry, "levels' of meaning."2 E.H. Gombrich, however, wishes to restrict our view of the openness of such images. He himself has found no text applying such an exegetical method to pictorial art nor any example of several divergent meanings present in a single pictorial representation. Instead, he speaks of how awareness of context and of genre will guide interpreters to a central "dominant meaning." 3 With this methodological warning, however, Professor Gombrich goes on to consider symbolic images such as personifications as much more than "decorative pictographs," or merely concepts translated into conventional images. In the Aristotelian tradition, exemplified by Ripa, symbolic images functioned as mnemonic or pedagogical devices for defining abstractions. The depiction of their attributes, moreover, offered a potentially sophisticated method of qualifying or developing the essentials of the abstraction portrayed. ${ }^{4}$ 
The link between pictorial representation and philosophical thought is stronger in platonic theory, witness Plotinus's discussion of the essence of Egyptian hieroglyphs:

... it seems to me, the wise of Egypt - whether in precise knowledge or by a prompting of nature - indicated the truth where, in their effort towards philosophical statement, they left aside the writing-forms that take in the detail of words and sentences - those characters that represent sounds and convey the propositions of reasoning - and drew pictures instead, engraving in the temple-inscriptions a separate image for every separate item: thus they exhibited the absence of discursiveness in the Intellectual Realm. ${ }^{5}$

The idea that true knowledge of the abstract Forms of the world, or of the Ideas in the Mind of God, is most accessible in visual form is diffused throughout platonism. The platonic Ideas, whose potency generates the lower forms of life, can be suggested or approximated by a visual image far more effectively than they can ever be approached by discursive discourse. Just as the Idea contains within itself all potential actualizations, so a single image can give rise to a succession of meanings, each appropriate to another level in the infinite process of manifestation. These meanings are not divergent, but linked by analogy. In discussing symbols that are believed to be essential rather than conventional, Professor Gombrich notes

their interpretation in itself must be left to inspiration and intuition. The reason is not far to seek. Conventions can be learned, if necessary by rote. The symbol that presents to us a revelation cannot be said to have one identifiable meaning assigned to its distinctive features. All its aspects are felt to be charged with a plenitude of meanings that can never be exhaustively learned, but must be found in the very process of contemplation it is designed to engender. ${ }^{6}$

Many platonists connected the representations of classical gods with the bodying forth of the Ideal realm in matter. Ficino went so far as to link the planetary deities with the formal power shaping the universe and, as a result, his images of these gods are talismanic, meant to exercise real power over the minds and bodies of men. ${ }^{7}$ A specifically Ficinian neoplatonism, however, is by no means a necessary component in the symbolic use of figures of the gods. Haedus makes no mention of Ficino, yet within his work one encounters nonetheless the openness of the image and its superiority to logical discourse as a source of truth.

The comprehension of truth - seeing the image with the eye of the mind, so to speak - works towards its acceptance. It should be kept in mind that the reading of images had a heuristic function. Of course, the idea that pictures could exercise emotive moral force was very old, part 
of the tradition of ekphrasis which concentrated on the moral education to be gained through instruction in looking at paintings. From Philostratus to Vasari and beyond, the concern is with content, not style; the emotions read into the pictures are those the commentator wishes to evoke in his reader. ${ }^{8}$ It is clear that the medieval my thographers worked in a decidedly moralistic tradition, designed to exploit the reforming influence of the images of the gods when rightly interpreted within a Christian framework. Prudentius, Fulgentius, Albricius, the anonymous author of the early Ovide Moralisé, and many that followed, continued the Stoics' attempt to rescue mythology from charges of impiety and frivolity through moral allegory.

These insights into the functioning of symbolic images in the Renaissance hold considerable promise for anyone interested in the use made of analogous images in literature. However, can a modern critic, very aware of differences between the way one looks at pictures and the way one reads a poem, allow an easy transfer here to the interpretation of the verbal icons so often encountered in The Faerie Queene, for example? Here Aristotelian and not behavioural psychology is relevant. According to Aristotle, even speculative thought can subsist in the human mind only within the terminology of pictures. The phantasmata, the stuff of thought, are forms or images produced from sensory experience of all kinds:

the objects of thought - both the so-called abstractions of mathematics and all states and affections of sensible things - reside in the sensible forms. And for this reason as no one could ever learn or understand anything without the exercise of perception, so even when we think speculatively, we must have some mental picture of which to think; for mental images are similar to objects perceived except that they are without matter. But imagination is not the same thing as assertion and denial; for truth and falsehood involve a combination of notions. How then will the simplest notions differ from mental pictures? Surely neither these simple notions nor any others are mental pictures, but they cannot occur without such mental pictures. ${ }^{9}$

The conviction that thought worked pictorially tended to obliterate distinctions between visible and verbal images, as Haedus's Anterotica illustrates. A close examination of this simple text suggests a number of ways in which the peculiar virtues of symbolic images find specifically literary expression.

The spirit of Haedus's Latin dialogue on love is caught in this description of its three books: "in the first of these he [Haedus] lists the misery and the sufferings of lovers; in the second he prescribes remedies, as much preservative as curative; and in the third he urges love of heavenly hings and of God; and shows the temporal good and eternal happiness hat come in consequence of that holy love."10 
Haedus was a theologian and moralist, who was born and raised in Pordenone in Friuli, and throughout his life associated with the Confraternità dei Battuti di Pordenone. Generally he used the Latin form of his Italian name, Pietro Capretto or Cavretto. Relatively little is known of the details of his quiet scholarly life, though Liruti has unearthed contemporary estimates of him that are very high indeed. Correspondence between Haedus and Count Jacopo da Porcia indicates that Haedus represented to those around him the new man of the emerging Renaissance culture. He is measured against the ancients and reassured that "nothing but years" stands between them; he is addressed as the first light in the dawning of a new golden age. ${ }^{11}$ Francesco Fattorello too calls him the first humanist of Friuli and backs his statement with a catalogue of Haedus's literary interests and achievements. ${ }^{12}$

Two others take part in Haedus's dialogue and they also figure in the cultural history of Friuli: Quintus Aemilianus Cimbriacus, a poet, and Antonius Philermus, a rhetorician. The first, Giovanni Stefano Emiliano, took the name Quintus and added Cimbriacus to denote his birthplace, Vicenza. ${ }^{13}$ The second, Antonio Fregoso, a self-named "lover of solitude," was the author of many works, most notably La cerva bianca de magnifico cavaliere. ${ }^{14}$

The dialogue is overtly didactic. In a proem before each book Haedus addresses his nephew Alexander, about to enrol at the University of Padua. These proems warn of the dangers for "young men of unformed character" in the university towns where academic life is corrupted. Near the end of the proem to Book One, Haedus's description of the socalled scholar, too proud to learn because he must first admit to lacking knowledge, ends with an image of blindness: "he prefers both to seem and to be blind with his eyes open rather than to dispel the shadows by administering a collyrium." The topic of wilful blindness leads immediately to a consideration of the blind Cupid and Haedus offers as a timely warning the record of his discussion of love with Cimbriacus and Philermus. As the doubter who must be convinced, Cimbriacus stands for Alexander within the dialogue, while Alexander himself mediates between the text and reader. Early in Book One Antonius hopes that all who hear of their discussion are filled with "credulitas et cautio" (I:ix).

Antonius dominates Books I and II, using an allegorical technique with pictorial roots analogous to the method of the emblem book. The three friends meet at the house of Aemylianus where they find a painting of Cupid, a painting which sparks off their discussion, but is in fact not illustrated in the text. Its details provide the structure for Book I, a tight relationship of attribute and allegory. In Book II where the subject moves away from Cupid to his twin Anteros, this pattern begins to break down into a loose series of topics, best described as a remedia 
amoris. In Book III, however, Haedus enters the discussion and reinstates the earlier method with interesting results.

Although Antonius offers to investigate the nature of Cupid and his attributes thoroughly (he is after the whole truth of the matter), what he offers is not a comparative study of different points of view on love, such as Equicola and Cartari later produced. Instead, he presents a highly selective series of details developing a single perspective. His analysis falls into three main blocks: the first deals with the identity of Cupid, the second with his appearance according to both the poets and painters, and the third and longest with the significance of that appearance.

Antonius establishes the parentage of his Cupid in a manner too muddy to elucidate here; eventually he emerges as the son of Venus and Mercury, that is, of lust and the body's sexual impulses (I:iv). His basic source is Cicero's De Natura Deorum III:23:60 where Cotta enumerates the three Cupids, one the son of Mercury and Diana, one the son of Mercury and Venus and one born of Mars and Venus and called Anteros. A basic problem arises here because Antonius cannot agree with poets such as Ovid (Metamorphoses I:466-71) who characterize Cupid as a "twin" god in the sense that he has a double function, that is, he both inspires and extinguishes passion by the use of his two kinds of arrows. Panofsky tells us that the Renaissance was aware of the fact that Anteros was, in antiquity, the god of reciprocal love. ${ }^{15}$ This Antonius refuses to accept because he wishes to make him instead Cupid's enemy, the champion of chastity who drives out lust. He thus splits the traditional dual function of the one figure into two (I:vi). The interpretive difficulties Antonius encounters here are temporarily resolved by Haedus (I:x), an early indication that Haedus will eventually supplement and correct all of this commentary.

Antonius cites four literary sources for the image of Cupid. He begins with Ovid's Metamorphoses I:466-71, which describes the winged god shooting from Parnassus with his two kinds of flaming arrows, then moves on to Amores I:2:19-42 where Cupid is presented as a charioteer. He draws from Vergil his definition of love as "nothing other than a certain "hidden fire" which "once entering the chest eats the heart and like poison runs through the veins and, clinging to the bones, devours their marrow" (I:x). Petrarch corrects and supplements Ovid, who did not realize the god's full cruelty and neglected to mention his varicoloured wings. Obviously referring to "The Triumph of Cupid," Antonius adds that he is nude, seated on a fiery chariot drawn by four fierce white horses and surrounded by suffering captives. From Apuleius comes the final detail that Cupid's wings are covered with tiny feathers that continually flutter playfully (The Golden Ass V:22). 
The painters are briefly passed over, unfortunately without contemporary reference. According to them, it seems Cupid is often painted with a crown of laurel, gold or myrtle woven with jewels; his golden curls are spread over his white neck; he is blindfolded rather than blind; he is sometimes painted "flammeus," sometimes with "a natural pleasantness of colour" (I:vii). The image Antonius is elucidating has become a composite of many illustrations.

Most of the rest of Book One (I:x ff.) is devoted to short exegeses of each of Cupid's traditional characteristics. He is a boy because of his playful nature, because he thinks his conduct is always excusable, because he is fascinated by worthless and even disgusting objects, because his passion for these breaks out in tears and anger if denied, because he avoids work, because his speech is often silly or lisping, because his amiability makes many friends quickly. Finally, like a boy he gets older and stronger every day.

It is obvious that all of this commentary is not functioning on the same level. His boldness and playfulness are the personality traits of the putto-god of classical mythology, while most of the others belong to the intemperate lover of courtly tradition and the final comment relates to the passion of love itself felt as psychic force. These three elements are continually interwoven throughout the discussion with the last two predominating.

Cupid's beauty is a bait, allowing him both to capture and be captured by others. His blindness evokes quite a lengthy disquisition from Antonius (I:xii). Led only by passion, Cupid suffers from moral myopia; he cannot see his own dishonourable conduct for what it is and assumes it is equally hidden from others. He is blind to the evils of women and to the shameful nature of his indulgences. The painters' conception of a blindfold Cupid is praised because it underscores the wilful nature of his blindness, representing as it does a kind of deliberate overturning of the proper hierarchy of reason and the will and appetite. To illustrate his point, Antonius provides this exemplum: "A certain Theotimus, troubled with a grave disorder of the eyes, loved his wife very much, but was forbidden by his doctor to have relations with her. However, his desire was so strong and impetuous that he could not control the outbreak of his lust. Thus, knowing and understanding that he would lose his eyes, he took her to bed in the fury of his desire saying, 'Farewell, dear light" "' (I:xiii).

Antonius's allegory moves closer and closer to an identification of the figure of Cupid and the lover and the section on the significance of his nakedness continues this trend (I:xiv). Cupid discards all but the single object of his passion; he cannot hide his love; he is, in Antonius's phrase, "naked of all goods." Here Antonius develops the theme of the 
four types of good - of soul, of reputation, of body and of fortune and how love destroys each, drowning out Aemylianus's weak objections in a tirade against sensuality as "nurse and inventrix of vices." It is doubly impossible for a man in love to devote himself to letters because he forfeits his reason along with his liberty when he becomes a slave to passion. Obsessed by the body, he has neither time nor inclination for things of the spirit. So far is Antonius from Spenser's conception of love as "root of honour and all vertue" that, if a man should cultivate some talent out of love, it is to be counted a blemish rather than an accomplishment (I:xvi).

Antonius moves on to deal with Cupid's wings and again the characteristics educed are mostly those of the lover. He flies because he is always quick to pursue pleasure. Once he attains his desire, he leaps with such joy that he seems to fly; he is so fickle and unstable that he can be said to rush in all directions as though flying. Here, Aemylianus offers a brief comment assuming love as a natural force: "Indeed, he can rightly be called winged since he flies through the universe and the world and conquers, not only man, but the beasts" (I:xvi). This Antonius quickly refutes with the claim that Cupid's only victims are those weaklings who surrender. He then goes on in incredible detail to equate Cupid's two wings with the lover's hopes, while their many colours signify numberless attempts at seduction and their tiny plumules are like a lover's innumerable lascivious thoughts (I:xix).

Having all but exhausted the details of Cupid's appearance, Antonius begins to explain the apparent paradox of a god both kind and cruel. At the beginning, it seems he soothes the wound he has made, only to drive his victims to a fury of anguish later. Aemylianus objects first that what Antonius calls the pains of love are dear to the lover and further that only a disobedient servant is punished by his lord. To Antonius, however, misery is misery and, while it is true that the willing suffer less than the rebellious, those who never give in do not suffer at all (I:xx). Here the commentary has reverted to a treatment of Cupid as psychic force and it remains on this level throughout the discussion of his weapons, their use and their effect.

Ovid called his arrows, not golden, but gilt (i.e. auratum rather than aureum), thus plainly indicating the deceptive nature of love's seeming good; at the same time, their sharp points indicate the serious and penetrating nature of the emotion. These highly dangerous arrows strike the idle or careless especially often (I:xxi).

Each part of Cupid's weaponry has a particular significance: the bow represents the hidden ambush in thoughts of pleasure, the bow-string represents delight, the quiver free will from which feelings of consent emerge and the arrows those same feelings - just as arrows destroy the 


\section{8 / Renaissance and Reformation}

body, such feelings destroy the soul. Thus, Antonius establishes the general nature of the emotion he wishes to document, the state of mind in which it is most easily induced and finally, produces a graphic account of the actual psychological process involved in "falling in love" by describing the shooting and striking (I:xxii).

The final items in Cupid's armoury are the flaming points of his arrows described by Ovid. These obviously must represent the burning anguish which spreads through the body of the lover and the inner fire so kindled accounts for lovers' blushes and that curious fact, mentioned earlier, that Cupid is sometimes painted "flammeus" (I:xxiii).

The rest of Antonius's exegesis is concerned with a variety of points: Ovid's description of Cupid shooting from Parnassus, his horse-drawn chariot, his many victims, and two final aspects of his appearance, his hair and his crown.

A number of ingenious reasons are given supporting the appropriate nature of his shooting from the top of Parnassus. He is, of course, hunting Apollo, but Antonius goes on to say that the summit indicates his predilection for those in high places and Bacchus's association with the mountain brings to mind the vulnerability of those fond of drunken revelry (I:xxiv).

Cupid's chariot Antonius interprets as the human heart and the four horses pulling it are the emotions of fear, lust, joy and grief. They are wild because they do not recognize the restraining power of reason and white because that colour signifies the weakness of both mind and body. Each of these passions, or morbi as Antonius says the Greeks called them, is treated at some length as they drag the heart of the unhappy lover hither and yon (I:xxv-xxvii).

Cupid's victims fall neatly into four categories: the capti who tend to fall in love easily and often, the vincti who are actually in the clutches of a woman, the vulnerati who have been long in love's service and the mortui who have given up their souls to debauchery (I:xxvii).

The god's head of golden curls comes in for detailed comment. The twisted strands represent the deceptive snares laid by false happiness. Just as hair is superfluous to the body, this much-sought happiness is worthless. The blonde colour signifies youth, the time when sexual urges are strongest. Its waves remind Antonius that pleasure is like the sea - bitter and turbulent - while the fact that the curls rest on the neck, symbol of human freedom, indicates the slavish weakness induced by love (I:xxix).

Over Aemylianus's objections, Antonius denies Cupid the glory of the triumphal crown of gold or laurel belonging to the conqueror and awards him instead only Venus's branch, the myrtle, traditionally offered by the Romans to the commander who had won a bloodless victory. 
The jewel in his crown is the false image of the highest good fabricated by desire and its light flashes many colours over his hair just as insatiable desire always seeks new ways to its end (I:xxx).

Antonius concludes (I:xxxii ff.) with a list of the enemies who lie in wait to attack the man attempting to live a celibate life: his own body desires sexual gratification; the devil lays the temptations of pleasure in his path; the bad example of dissolute men may lead him astray. His discussion of Anteros is promised as instruction for the eager tyro in how to avoid this tri-partite lure of the world, the flesh and the devil and he hopes that his revelation of the true meaning of Cupid's image will return their sight to those blinded by sin (I:xxxii).

Antonius has used a kind of emblematic technique in order to organize his thoughts on the subject of love. Although his only specific references are to verbal depictions and no. illustrations accompany his text, the whole treatment has strong pictorial roots and the actual image is kept firmly in mind as appropriate significations are drawn from it. The method is similar to that used by John de Ridevall who also painted word "pictures" and then extracted their hidden meanings, although by the less sophisticated procedure of elucidating the legends he found inscribed on them.

Once having settled on his relatively classical image, Antonius wastes no awe upon it. He has no scruples about fully developing its details by adding the crown, for instance. He resembles in this the much earlier author of the Ovid Moralisé who goes so far as to discuss why the tailfeathers on Cupid's arrows are made in two parts (11.3330 ff.). Nevertheless, Antonius's Cupid appears relatively free from medieval accretion; he has no talons like those described by Guitton d'Arezzo or Francesco da Barberino. However, he is blind.

Panofsky has discussed how this characteristic evolved as part of a moralizing mythography which interpreted the gods in explicitly Christian terms. Whether this blindness can always be so firmly disposed of as he suggests is open to doubt. It is after all an ambivalent concept calling on many traditions, as he himself acknowledges. ${ }^{16}$ It does seem, however, that used with tact the doctrine of the two loves drawn from St. Augustine's De Doctrina Christiana III:10:16 can be extremely helpful in assessing the significance attached to this attribute by various authors. According to Panofsky, the blind Cupid opposes caritas; he represents the demonic form of love which moves away from God and seeks to establish some mutable good as the source of value in the universe. This is certainly the Cupid Antonius describes. Ambiguities disappear as he juxtaposes his blind Cupid with Anteros, a figure who then emerges solely as a castigator of the flesh rather than as a champion of any holier love. 
Antonius brooks no debate - his message is sharp and clear. His Cupid is very much on the wrong side of the moral world whether identified with the lover caught in love's toils or the obsession itself at work. At times this vindictive little god comes close to assuming the life-force of a true daemon, of achieving hypostasis, but Antonius is always careful to nullify any such dangerous tendency. This, he feels, is what the poets and painters want us to think; in a sense they have invited us to excuse the lust within ourselves by projecting it outward upon this boyarcher. Antonius wants to destroy these pretty fictions and return the reader to a sense of shame and responsibility for his own actions. The difficulty is that he has weighted his case too much. The broader meanings of cupiditas are sacrificed for an identification of Cupid with purely sexual matters. The relationship between man and woman is narrowed to the sexual alone and Cupid is castigated, not only as the god of illicit sex, but very nearly as the god of sex itself, a position which markedly undervalues Christian marriage. The figure of Anteros shows how sympathy for the Greek definition of emotion as disease has moved Antonius into a position where rejection and isolation are the only paths to virtue.

Antonius, the celibate ascetic, dominates until the end of Book II, when Haedus is invited to judge the merits of his presentation. The priest offers polite praise, but observes that, despite the truth of some of these observations, the nature of love is yet to be revealed. Book III throws considerable light on the way the allegorical interpretation of images of the gods was regarded by the end of the fifteenth century, even in the cultural isolation of Friuli.

Haedus begins by relating his dream of a pitifully misunderstood Cupid, a Cupid "non pinto ma vivo," as Petrarch calls him, who comes to accuse Antonius of defaming his character in these words:

I am placed in a man's nature so that I can bring about nothing of my own accord, I can plan nothing and I can attempt nothing, since I am obedient to the will from which comes all the force both of body and soul. Therefore, the poets appropriately called me twin since I must bend now one way and now another, in accordance to the freedom of the will and the quality and character of the mind. Therefore, since I must be obedient and accommodating, how can anyone be angry with me when I fulfil this duty? The cause and not the effect deserves praise and blame (III:lvii ${ }^{\mathrm{V}}$ ).

The complexity ignored by Antonius's approach here reasserts itself in the essentially potential nature of this "twin." No simple definition can exhaust love, least of all one equating it with sexual indulgence and no more. Haedus reproaches Antonius both for his complete condemnation of appetite and for his exclusive concern with sexual behaviour: 
You have proceeded so far Antonius as if appetite were the author and cause of lust and this impulse can be situated only in acts of love. But, in addition, we seek riches, honours, nobility, power, health and an unending variety of things of this sort which either are or seem to be good. There can be no doubt we seek these things either virtuously or sinfully.....It appears that appetite is not a cause of wickedness, since we can use it well and since it was placed in our soul by God. It is not blameworthy, but man's will abuses it (III.lix ${ }^{\mathrm{v}}$ ).

Haedus defines Cupid as love, love directed by the will toward the good or, at least, toward what seems the good, and he supports this by recourse to the method of Book I: "Cupid is nothing other than love since the image of Cupid seems to refer to nothing other than the passion and ways of the lover" (III: $\mathrm{xcii}^{\mathrm{V}}$ ). Immediately, Antonius attempts to justify his identification of Cupid with lust by reference to his shooting and striking. But here the consequences of the emblematic method make themselves felt. Its strength lies in its breadth of reference and synthetic power. As we saw, even Antonius's narrow excursion into mythography functioned on a variety of levels and, at this point, it is no longer possible to appeal to the image as some kind of final arbiter.

The two opponents set up a counterpoint of statement and restatement, each side vainly appealing to the image as authority for a definitive proof. This tension is resolved, however, not by asserting the superiority of any one position, but by exploiting the resources of the emblematic method itself to integrate the two. Antonius has sought to impose a limit on the significance of the image of Cupid; Haedus removes it. All types of love have the same nature and force and Cupid's image relates to them all. An elaborate parallel is drawn between the courtly lover and the devout Christian; both desire and praise; both laugh and exult; both beg and serve. Each illuminates the nature of the other and some part of the transcendent force of love is expressed in both (III.lxxxiii).

Just as Antonius has described one aspect of the "twin" Cupid, Haedus now sets out to investigate another. In the process the positive ideal so obviously lacking in the previous discussion emerges as the Augustinian concept of caritas taken from De Doctrina Christiana III: x: 16. It gradually takes on the character of mutual love, in the sense of virtuous friendship, which was denied Anteros. A two-fold concept, caritas encompasses both the human and divine, one's relationship with others as well as with God. Haedus sets out to describe society as a hierarchy of love - ties of family, community, and citizenship are emphasized in a framework built of the love of God.

It must be understood that Haedus is not replacing Antonius' interpretation with another, but instead expanding it beyond the narrow limits first imposed upon it. His treatment of Cupid exhibits those 
characteristics isolated as important features of Renaissance emblematics. Even for Haedus, a figure remote from the rising influence of Ficinian neoplatonism radiating from Florence, a hard-edged interpretation of Cupid is impossible. Standing as he does midway between emblem book and the allegorical use of the images of the gods in fictions, he provides a bridge between pictorial iconology and its carry-over into problems of interpretation wherever these images may occur - in fine arts, in court ceremonial or in literature. In his hands too, the image has infinite range; its openness places it beyond discursive explication so that it cannot be utilized to close a logical argument. At the same time, it holds the key to understanding and action and because of this it remains intimately connected with a moral tradition. Rightly understood the figure of Cupid provides man with access to the flow of energy in the Christian cosmos - the redeeming cross-current between God and man called caritas.

Haedus is not a sophisticated literary stylist; his instructional purposes often overwhelm his fictional mode. Nevertheless, Book One is more than a straightforward philosophical dialogue. It takes place in a fictional world, a Roman Friuli, a Pordenone become Portusnaensis, in which the toga-clad speakers go by classical names, imitate the peripatetic philosopher, and gather on the calends of May for their discussion of love. In Book One character and incident loom large, while at the same time forming part of the intellectual focus of interest. The three friends meet for dinner to find Aemylianus engrossed in a portrait of Cupid. Their banter over the meal promises serious discussion, so they set off for Haedus's gardens outside the city where they can debate in comfort. On the road they encounter Helia, the object of Aemylianus's love sickness. Brief as it is, their confrontation serves to illustrate Antonius's remarks and this intimate connection between the speakers and their subject matter adds interest and more than a little humour to Book One. Books Two and Three are uninterrupted discussions held at Haedus's home on the following day. Through most of Book Two Antonius and Aemylianus are still at loggerheads, with Haedus's quiet voice interrupting on occasion to clarify a point. At the end, however, Aemylianus performs an annoying about-face. He restores his dignity by claiming that he has been pretending to disagree only to test his opponent. Whatever dramatic tension that might have lingered is dissipated instantly. As the books become progressively more concerned with things of the spirit the conversational element, the joking banter and even the searching questions gradually cease and Haedus's last book comes to its end closer to sermon than dialogue.

Nevertheless, the author of the Anterotica clearly shows his awareness of the literary possibilities of symbolic images for manipulating point of 
view and building a sense of cohesion. The proems establish Haedus as a self-conscious dramatized narrator; Antonius also assumes this role, but in Book Three an ironic distance is created that causes the reader to reject the one narrator and form a bond with the other.

Wayne Booth's analysis of how irony functions as "rejection" followed by "reconstruction" clarifies this process. According to Booth, a reader may take up an author's invitation to reject the first meaning of the text and to join in building a new meaning that provides a vantage point overlooking the first. The four steps of "reconstruction" involve this rejection of the first meaning (prompted by some incongruity between the words and something else the reader knows), a consideration of alternatives other than intentional irony, a decision about the author's intention and finally a choice of a new meaning with which the reader can rest secure. ${ }^{17}$ Such a coordination of the efforts of author and reader leads to their identification in a community of agreement that is emotionally binding and especially appropriate to works of an educative nature. ${ }^{18}$ Commenting on irony in earlier literature, Booth has noted its tendency toward weakness, due to a lack of adequate warning of the presence of such irony or to our own inability to comprehend the nature of the warnings given. ${ }^{19}$

Is the unmasking of Antonius sudden and unexpected, or are "warnings" of the kind Booth looks for given by the text? A few can be made out. Certain generic expectations go along with our recognition of this as a Ciceronian dialogue, among them the feeling that the third book will carry most weight and the early realization that this particular dialogue is strongly Christian and overtly didactic. Antonius restricts himself to classical authorities for the most part and sports a humanist morality rather separate from Christian doctrine. From the beginning Haedus, though reluctant, is established as arbiter and he does, as I have already noted, show his superior powers of interpretation early in Book One. Nevertheless, Antonius's credentials are very good and the reader has little reason to mistrust him, except the very reason that Haedus himself adduces, a sensitivity to the right way to read images. Haedus points out Antonius's fallibility as a Christian moralist by pointing out how, as narrator of Book One and Two, he misused his emblematic technique. The single most important indication of the coming reversal is the very presence of the image for interpretation. Its openness stimulates the reader's pleasure in deciphering and simultaneously invites distrust of a simplistic interpreter. Once armed with the superior awareness revealed in Book Three, the reader can reject Antonius's reading, but not completely. The inherent qualities of the symbolic image forbid the simple reversal of meaning that Booth guards against in his discussion of "rejection" vis à vis "reconstruction." 20 Because of Haedus's acknowl- 
edgement of the synthetic powers of the image, the reader can rest with his interpretation, even though the meaning he advances is not finite, local and limited in quite the way one might expect from Booth's definition of "stable" irony. ${ }^{21}$ As E.H. Gombrich suggested was the most common methodology, Antonius's meanings here are tested against the context of genre and coordinated with respect to a single dominant meaning.

Wolfgang Iser describes reading as a phenomenological process in which "we look forward, we look back, we decide, we change our decisions, we form expectations, we are shocked by their nonfulfillment, we question, we muse, we accept, we reject." 22 These responses are guided by the interplay between familiar and unfamiliar, by "illusionforming" and "illusion-breaking." Iser cites Booth's "unreliable narrator" as one of the literary devices that result in increased tension between our expectations and our distrust. The presence of the unreliable narrator results in a "defamiliarization of what the reader thought he recognized" and leads via this to an immediate experiencing of the text, ${ }^{23}$ a kind of first-hand experience that may account for the emotional commitment Booth sees accompanying stable ironies.

It seems to me that another technique, now lost to us, for engaging the reader with the text in this way is the ironic use of symbolic images. Norman Knox's discussion of the history of the word "irony" is shaped by post-Renaissance concerns. However, he does point out that Fraunce and Puttenham, following Quintilian for that matter, consider irony together with allegory because, he says, both devices exploit a discrepancy between text and meaning, a discrepancy the reader attempts to harmonize. ${ }^{24}$ By its very nature, the symbolic image stimulates both familiar and unfamiliar readings and prompts an effort towards an integration of these; it sets the reader in a questioning stance towards interpretations offered within the text as they arise. The lively interaction of author and reader so encouraged may, as I think it has, contribute much to the great textual density and richness in works employing such images. Offsetting the danger of fragmentation and confusion, is the capacity for synthesis within the same figure, a capacity that offers the skilled writer a device that is, in fact, very like allegory in another important respect. It too shares the ability to combine the individual and the universal in one, to coordinate the "rejection" and the "reconstruction" in an apprehensible whole.

The mythographic manuals have important information to offer the study of symbolic images, information available from few other sources, but because of their systematic arrangement as compendia, their use has tended to isolate individual images in literary works where the mythographic details may form part of larger patterns. These are pro- 
blems for consideration in the light of each text but, to judge by Haedus's example, it should not be surprising if symbolic images in sophisticated literary form are carefully chosen and organized for specific literary purposes, such as the establishment of point of view and the coordination of broad reaches of significance. In Haedus's Anterotica, the same method that reveals the limitations of Antonius, is used finally to orchestrate a range of meanings, drawn from the image of Cupid, that unify the dialogue and work to further its central purpose - the education and confirmation of the reader in Christian love.

\section{McMaster University}

\section{Notes}

1 Petrus Haedus, Anterotica: De Amoris generibus (Treviso: Gerard of Flanders, 1492).

2 George Boas, The Hieroglyphic of Horapollo (New York: Pantheon, 1950), p. 38.

3 E.H. Gombrich, Symbolic Images (London: Phaedon, 1972), pp. 15-22.

4 Ibid., pp. 139-45.

5 Plotinus, The Enneads, trans. Stephen MacKenna (2nd ed.; London: Faber \& Faber, 1956), $\mathrm{V}: 8: 6$.

6 Gombrich, p. 159.

7 See his Libri de Vita (1489), Book III.

8 Svetlana Alpers, "Ekphrasis and Aesthetic Attitudes in Vasari's Lives", JWCI 23 (1960), 190-215.

9 Aristotle, On the Soul, trans. W.S. Hett (2nd ed.; Cambridge, Mass,: Harvard University Press; London: Heinemann, 1957), III, viii.

10 Gian-Giuseppe Liruti, Notizie delle vite ed opere scritte da' letterati del Friuli (Udine: Gallici alla Fontana, 1760-80), I, 432. The translations from this and the Anterotica are my own.

11 Liruti, I, 432-36.

12 Francesco Fattorello, La Cultura del Friuli nel rinascimento (Udine: Arti Grafiche Friulane, 1938), pp. 20-39.

13 See Fattorello, p. 49; Vincenzo Lancetti, Memorie intorno ai poeti laureati (Milan: Manzoni, 1839), p. 174.

14 See Francesco di Manzano, Cenni biografici dei letterati e artisti friulani (Bologna: Forni, 1884-7), 84; Liru ti, I, 411-13. Gilles Ménage's Ménagiana, ed. Bernard de La Monnoye (3rd ed.; Paris: Delaulne, 1715), II, 33, identifies Philermus with Antonio Fregoso.

15 Erwin Panofsky, "Blind Cupid" in Studies in Iconology (New York: Oxford University Press, 1939), p. 126.

16 Ibid., pp. 95-103.

17 Wayne C. Booth, A Rhetoric of Irony (Chicago \& London: University of Chicago Press, 1974), pp. $10 \mathrm{ff}$.

18 Ibid., pp. 29, $41 \mathrm{ff}$.

19 Wayne C. Booth, The Rhetoric of Fiction (Chicago \& London: University of Chicago Press, 1961), p. 317.

20 A Rhetoric of Irony, pp. $106 \mathrm{ff}$. 


\section{6 / Renaissance and Reformation}

21 Ibid., p. 3.

22 Wolfgang Iser, The Implied Reader (Baltimore \& London: Johns Hopkins University Press, 1974), p. 288.

23 Ibid., pp. 289-89.

24 Norman Knox, The Word Irony and its Context, 1500-1755 (Durham: Duke University Press, 1961), pp. 5, 10. 